\title{
The Disorder Named Koro
}

\author{
RIMONA DURST and PAULA ROSCA-REBAUDENGO
}

Talbieh Psychiatric Hospital, Jerusalem, Israel

Correspondence: Dr Rimona Durst, Head, Acute Ward, Talbieh Psychiatric Hospital, POB 39, 91000, Jerusalem, Israel

\begin{abstract}
The koro syndrome is a triad of deep-seated fear of penile shrinkage, its disappearance into the abdomen and consequent death. The disorder, which is considered culture related, is endemic in South-East Asia and China, where it occurs in both epidemic and sporadic form. In the western hemisphere single cases are occasionally encountered. The association with psychiatric pathology in sporadic cases of koro has been well described, but lately attention has been drawn to systemic or neurologic involvement in these patients. The clinical, historical and cultural features of koro, as well as therapeutic strategies, are discussed.
\end{abstract}

\section{Introduction}

The term koro denotes a culture-related syndrome predominantly prevalent in South-East Asia and China. The afflicted patient is convinced that his penis is shrinking and will ultimately disappear into the abdomen, whereupon death is inescapable. If in this triad of subjective symptomatology one of the components is missing, or the syndrome appears outside the endemic areas, it is referred to as "koro-like" or "atypical koro". Sporadic cases of koro have surfaced in the western hemisphere, often in association with an underlying psychiatric or organic disorder. Koro-like manifestations call for thorough medical investigation so as to shed light on the etiopathogenesis and therapeutic implications. The present article reviews the clinical features, historical roots, cultural pathogenesis, and the occurrence of koro in epidemic and sporadic form. Folk-healing practices and modern therapeutic modalities utilized in patient suffering from the syndrome are discussed. Sixteen sporadic cases of Koro published in the literature since 1982 were collected and added to a previous compilation of 16 patients. A list of the five major epidemics reported since 1967 is also presented. Careful examination of the combined data reveals that a search for organic pathology, with emphasis on CNS involvement, is imperative in patients displaying koro characteristics.

\section{Definition of Malady and Symptomatology}

Koro is an enigmatic culture-related syndrome, currently unclassified in DSM-III-R (American Psychiatric Association, 1987). It is a unique 
disorder, in which the patient complains of deep-seated fear of penis shrinkage and its ultimate retraction into the abdomen. The patient is convinced that after final penile dissolution, death is inescapable. The syndrome, which may be triggered by acute anxiety, often assumes panic dimensions. The patient experiences profuse sweating, palpitations, dizziness or vertigo, tingling sensations and feeling of numbness throughout the body. His insuperable fear impels him to perform preventive manoeuvres, such as holding his penis, pulling it outward and showing it to others for reassurance (Yap, 1951, 1965). In the majority of cases, the attack is transient, lasting from minutes to days. Sexual inadequacy may pre-exist or appear as a sequela of the attack. In the female counterpart of the syndrome, occurring but rarely, the woman is afraid that her breasts or labia are shrinking (Arieti and Meth, 1959; Ellenberger, 1965; Nandi et al., 1983).

\section{Etymological and Geographical Background}

The origin of the word Koro is uncertain. In the Western medical literature the term was first used by Blonk (1895) and van Brero (1896). van WulfftenPalthe (1936) thought it to derive from the Malayan term kura (head of the tortoise) and noted that both the Chinese and the Malays use the expression "head of a turtle" for the glans penis, while Gwee (1968) designated the word keruk ("to shrink" in Malayan) as the most probable origin. Adriani and Kruijt (1912) and LeBar (1972) propose a geographical connection, in that the name may be associated with a river, its surrounding valley and a local tribe in the northwestern sector of Sulawesi, (Celebes) all bearing the name Koro. Suk-yeong (Cantonese) and suo-yang (Mandarin), ("retraction of the male sexual organ"; Yap, 1965; Tseng et al., 1988), shin-kuei ("heart defect") or shern-kuei ("spiritual defect") are descriptive Chinese terms also employed for the syndrome (Yap, 1965). Variants of these terms are the Thai word rok loo ("genital shrinking disease") and the Indian versions jinjinia bemar (Assam) indicating a disease characterized by a tingling sensation of the body (Dutta, 1983), kattao (North Bengal; "cut off') (Chakraborty et al., 1983; Westermeyer, 1989) and disco (Calcutta), a trendy term for any sort of novelty (Charkraborty et al., 1983; Nandi et al., 1983). Payne (as cited by Edwards, 1984) depicts a similar shrinking penis disease called lanuk e laso occurring in the Bogoba tribe of the Philippines, who ascribe it to the power of sorcery. A penis-shrinking syndrome, tira, believed to be caused by overindulgence in coitus, has been reported from the Cook Islands (Marshall, 1980).

\section{Historical Roots}

The first mention of shrinkage of yang (Chinese term for "the male principle") as a symptom signifying imminent death dates back to the Yellow Emperor's "Classic of Internal Medicine", the ancient Chinese medical textbook, presumably written in the 3rd century B.C. Suo yang 
(retraction of the male organ into the abdomen) refers to a syndrome in which the diminishing yang comes together with the fear of inevitable death. Later, other traditional Chinese medical books described suo yang as a fatal disease caused by retraction of the penis, nipple or other protruding organs (yang), including nose or tongue (Gwee, 1968; Tseng et al., 1988).

Sprenger and Kramer in their notorious book Malleus Maleficarum, published in 1489, mention apparent, transient disappearance of a man's genitals, and ascribe it to "glamour" cast over the man by witches. Some 200 years later, Guazzo, in his Compendium Maleficarum, compiled a list of sexual disorders, the seventh and last of which is "narrowing of the female genitals" and "retraction, hiding or actual removal of the male genitals". These aberrancies were also supposed to be due to a witch's spell, which causes the unfortunate victim to believe that his genital organ is retracting, or even succeeds to conceal it from his senses. This phenomenon may be interpreted as a true abstraction of the member in imagination, although not in fact (Trethowan, 1963).

Toward the end of the 19th century Blonk (1895) reintroduced the syndrome to the Western world, describing it as a malady indigenous to Western Sulawesi. Van Brero (1896) and van Wulfften-Palthe observed a few cases of Koro in what was the Dutch Indies. Over the last three decades, single occurrences of the Koro syndrome in non-Chinese subjects were occasionally reported in the professional literature (see below, Sporadic Cases).

\section{Cultural Pathogenesis}

The onset and perpetuation of culture-bound syndromes are considered to be linked with the moral/educational, social, mythological and psychodynamic background of a given population group, and they seldom extend beyond the boundaries of such particular culture (Nandi et al., 1983).

The koro syndrome is regarded as a culture-bound psychogenic phenomenon encountered chiefly in China and other regions of South-East Asia. The geographical origin of the genital retraction syndrome is difficult to trace. Did it derive from an ancient Chinese prototype that spread throughout Malay and neighbouring countries, or did it spring up independently in different cultural societies?

Suo yang, the Chinese form of koro is influenced and perpetuated by Chinese traditional education and sexual philosophy. In a culture known for its veneration of the older generation, parental warnings against masturbation are not lightly discarded. The prohibition, which is based on the rationale of its harmful effect on the genitals, is deeply embedded in the Chinese philosophy of harmony between the two basic principles of yin and yang ("feminine and masculine principles that combine to produce all that come to be"). According to this philosophical concept, a loss of yang or an excess of yin exert negative effects on the male (Malinick et al., 1985), while normal sexual intercourse between men and women allows a healthy exchange of yin and yang humours. It is believed that the semen is a precious 
substance and that a man should restrain his sexual desires, because not only will excessive discharge of semen (yang) result in a weakening of the mind and body, it will also determine death. Nocturnal emissions, masturbation, improper diet or exposure to cold, which all cause a loss of yang, are therefore dangerous to the male's vital energy (Malinick $e t$ al., 1985; Tseng $e t$ al., 1988). An ancient Chinese myth centres around the belief that a female ghost searches for and collects penises for the purpose of male ghost reincarnation (Tseng et al., 1988).

Witness to the fact that the notion of the Koro syndrome is strongly rooted in Chinese consciousness are the popular superstitions relating to prophylactic means against the disorder. For example, one is warned never to walk in front of a tortoise, because retraction of its head is a negative omen, nor to step over tortoise stool or horse hair (Edwards, 1984). It is also advisable not to pass near a water pond. Then there are the dietary taboos, such as refraining from eating too much yin food (e.g. bananas) and to shun a certain legumen called kentjoer (Kaempferia galanga), which means "retracts".

In its Malayan form, the manipulations surrounding the syndrome differ slightly from those described in the Chinese manifestation. For example, in the former the preventive manoeuvres may not be performed by the opposite sex, as this is supposed to be fatal to the victim, whereas in suoyang this prohibition does not exist (Edwards, 1984).

The disorder has generally been considered a culture-bound syndrome, owing to its circumscribed origin and Chinese etiopathogenesis (Gwee, 1968; Rin, 1965; Yap, 1965). However, in view of recent non-Chinese epidemics, as well as reports of sporadic cases in the West, the attenuated term "culturerelated psychiatric disorder" has been suggested (Tseng et al., 1988). The appropriateness of this term is exemplified by the Judeo-Christian doctrine which abhors onanism. The word stems from the biblical text in Genesis 38:8-10, where the story of Onan links masturbation (in Hebrew onanut) with punishment by death. The strong injunctions against onanism precipitate guilt feelings and fear of castration, which, in turn, activate unsuccessful attempts at solutions, symptomatically expressed in illusionary shrinkage of the penis (Levav and Bilu, 1980).

The common denominators between Jewish religious principles and Chinese philosophical concepts regarding sexual behavour are the rules on abstinence from self-gratification and the instructions toward harmonic sexual practice. The two fundamental beliefs hold the semen invaluable and recognize it as a substance not to be spent improperly or excessively. One of the commentaries of the medieval Jewish philosopher and physician Maimonides (1135-1204) treats of the regulations concerning sexual behaviour and the undue waste of sperm. Both the Shulhan arukh (Karo, 1979) and the Yellow Emperor's ying and yang theory mention the dire consequences of disharmonic sexual exchange. Although the text of the Shulhan arukh does not specifically dwell on the fate of the penis ["The semen constitutes bodily strength and the light of the eyes. To excessively spill semen is to spill the power of the body, and its life, and the light of the eyes"], the authority of 
this set of laws in Jewish culture and ethics may explain the relative frequency of Jewish koro patients among the sporadic cases (Durst and Rosca-Rebaudengo, 1988; Hes and Nassi, 1977; Modai et al., 1986).

\section{Underlying Personality}

Yap (1965) described Koro patients as immature, dependent, lacking confidence in their virility and being in constant sexual conflict. In case reports of single koro occurrences that also address the issues of its premorbid personality, the traits extant in the patients fit Yap's description. The patient presented by Scher (1987) was shy, immature, boyish and naive and, although considering it a sin, masturbated frequently. Cremona (1981) found similar characteristics in her case of a young Briton, an only son overdependent on his mother, who was preoccupied with self observation of his genitals. In epidemic events, involving sometimes thousands of young adults, the general underlying personality is portrayed in similar terms (Nandi et al., 1983; Tseng et al., 1988).

\section{Epidemics}

Most cases of Koro in Asia occur in epidemic form. As far as could be

TABLE 1. Epidemics of koro

\begin{tabular}{|c|c|c|c|c|c|c|}
\hline & Reference & rear & $\begin{array}{l}\text { Geographical } \\
\text { area }\end{array}$ & $\begin{array}{l}\text { Number } \\
\text { of cases }\end{array}$ & $\begin{array}{l}\text { Psychological } \\
\text { trigger }\end{array}$ & $\begin{array}{l}\text { Physical } \\
\text { trigger }\end{array}$ \\
\hline & $\begin{array}{l}\text { Koro study } \\
\text { team }(1969) \\
\text { Ngui }(1969)\end{array}$ & 1967 & Singapore & 469 & $\begin{array}{l}\text { Rumours of } \\
\text { poisoning }\end{array}$ & $\begin{array}{l}\text { Antiswine fever } \\
\text { vaccine in pork }\end{array}$ \\
\hline & $\begin{array}{l}\text { Jilek and Jilek } \\
(1977) \\
\text { Suwanlert- } \\
\text { Coates } \\
(1979)\end{array}$ & 1976 & Thailand & 2000 & $\begin{array}{l}\text { Rumours of } \\
\text { food poisoning } \\
\text { by the Vietkong }\end{array}$ & Rabies \\
\hline & $\begin{array}{l}\text { Ilechukwu } \\
\text { (1988) }\end{array}$ & $\begin{array}{r}1975 \\
1977\end{array}$ & 5 Lagos & $\begin{array}{l}\text { Not } \\
\text { given }\end{array}$ & $\begin{array}{l}\text { News report } \\
\text { of penis } \\
\text { disappearance } \\
\text { after contact } \\
\text { with strangers }\end{array}$ & - \\
\hline & $\begin{array}{l}\text { Dutta (1982) } \\
\text { Chakraborty } \\
\text { et al. (1983) } \\
\text { Nandi } \text { et al. } \\
\text { (1983) } \\
\text { Chowdhury } \\
\text { (1989) }\end{array}$ & 1982 & India & $\begin{array}{l}\text { Not } \\
\text { given }\end{array}$ & $\begin{array}{l}\text {-Rumours of } \\
\text { harm by } \\
\text { immigrants } \\
\text {-Fear of lethal } \\
\text { disease }\end{array}$ & $\begin{array}{l}\text { Cerebral } \\
\text { malaria }\end{array}$ \\
\hline & $\begin{array}{l}\text { Tseng et al. } \\
(1988)\end{array}$ & $\begin{array}{r}1984 \\
1985\end{array}$ & $\begin{array}{l}\text { Hainan- } \\
\text { (China) }\end{array}$ & $>2000$ & $\begin{array}{l}\text { Fortune teller } \\
\text { predicted } \\
\text { disaster }\end{array}$ & - \\
\hline
\end{tabular}


ascertained by us, five major outbreaks were documented in the literature since 1967 (Table 1). The epidemics were reported to be triggered by popular rumours or mass media communications. The process of contagion develops under, and is propagated by, socio-cultural stress (Hughes, 1985), political situations and commonly shared beliefs (Tseng and McDermott, 1981); individual psychopathology was seen to play a less important role ('Tseng et al., 1988). The epidemic manifestations of Koro have also been described as mass hysteria (Ellenberger, 1965) or epidemic psychosis (Harrington, 1982).

The most plausible explanation for the epidemic occurrences is arousal of deep anxiety concerning the continuity of the group as an ethnic entity, symbolized by fear of losing potency and the organs of reproduction. This assumption is substantiated by the fact that the epidemics appeared at a moment in time when social change was so profound as to imply loss of cultural identity (Ellenberger, 1965). Notwithstanding the emphasis placed on the psycho-social aspects involved in koro outbreaks, one should not overlook the fact that physical factors may also be conducive in the occurrence of the syndrome. Thus, in three of the five major epidemics antiswine fever vaccine, rabies and cerebral malaria were mentioned as concomitant features.

\section{Sporadic Gases}

Since the review by Berrios and Morley in 1984 of 16 non-Chinese patients with koro-like symptoms, 16 additional sporadic cases have been published in the literature (Table 2). In 13 instances in Berrios and Morley's series the koro manifestations were secondary to psychiatric disorders, in one patient they were recorded as having "no psychiatric history" (Constable, 1979), while in two cases the symptoms coincided either with drug abuse (Dow and Silver, 1973) or carcinoma (Lapierre, 1972). In 12 of the 16 cases compiled by the present authors (Table 2), the koro syndrome was associated with a documented physical illness: three cases were related to alcohol or drug abuse, three to CNS disorders, four patients had a background of urogenital symptoms, and in one case malaria seems to have been implicated, a fact that raises the question of cerebral involvement (Daroff et al., 1967; Westermeyer, 1989).

\section{Therapeutic Modalities}

The treatment approaches can be divided into four main avenues: (1) preventive measures as prescribed by the culturally embedded myths (see cultural pathogenesis); (2) manipulatory strategies (pulling the penis outward, fastening of clamps and strings to the penis) performed by the patient himself, family members or friends; (3) folk healing suggestions to combat the disorder, including special diets containing yang substances (e.g., bamboo, deer horn, red pepper jam, black pepper powder, ginger) 
(Edwards, 1984; Tseng et al., 1988) and performance of rituals to chase away the evil spirit (striking gongs, setting off firecrackers); (4) the modern medical conception, which takes into consideration the possibility of koro superimposed on a psychiatric disorder, secondary to an organic illness, elicited by a psychological trigger, or any combination of these. That koro often has a multifactorial etiology emerges from the data summarized in Tables 1 and 2.

The sporadic cases compiled by Berrios and Morley (1984) and those gathered by the present authors show that physical and mental components are involved in koro (Table 1). Of interest is the information in Table 2 which demonstrates that besides psychological triggers, tangible elements (poisoned food, vaccines, cerebral malaria) may have been causative factors in the development of the syndrome.

The multifactorial etiology of koro warrants holistic investigatory and therapeutic measures. Accordingly, physical examination, laboratory tests, radiologic imaging and psychiatric evaluation will afford appropriate treatment planning. The treatment may include psychopharmacological medication (benzodiazepines, neuroleptics, antidepressants), physical modalities, such as electroconvulsive therapy (Shukla and Mishra, 1981; Durst and Rosca-Rebaudengo, 1988), or psychotherapeutic intervention (reassurance, supportive or dynamic oriented). The different psychotherapies aim at relieving the castration fears and sexual conflicts which form part of the picture in most of the patients. Dissolution or amelioration of a co-existing organic disorder may have a beneficial effect on the disorder.

\section{Comment}

The koro syndrome does not fit into any particular diagnostic category. In keeping with its multifactorial etiology, its appearance has been attributed to socio-cultural, psychological-psychiatric and organic-neurologic triggers. The socio-cultural aspects that may bring about koro were mentioned earlier in the text. As to the psychological-psychiatric elements, the syndrome has been linked to a host of psychopathologies, such as depression (Kraepelin, 1921; Weller and Ameen, 1982; Westermeyer, 1989); obsessivecompulsive disorder (van Brero, 1896); depersonalization syndrome (Yap, 1965); acute stress response (Rosenthal and Rosenthal, 1982); acute adjustment disorder (Gwee, 1963); panic attack and acute anxiety (Rin, 1965; Levav and Bilu, 1980); shared paranoid disorder (folie à deux) (Westermeyer, 1989); epidemic hysteria (Legendre, 1908; Jilek, 1986); acute psychosis (Shukla and Mishra, 1981) and schizophrenia (Bychowsky, 1943; Cremona, 1981; Devan and Hong, 1987; Edwards, 1970; Yap 1965).

Due to its heterogenous linkage, koro has not found an unequivocal place in the current psychiatric classifications of ICD9-CM (1978) and DSM-III-R (1987). Yet, koro when superimposed on a documented physical pathology clearly belongs under the heading of Organic Delusional Syndrome (293.81 in ICD9-GM and DSM-III-R). 
TABLE 2. Sporadic cases of koro (1982-1989).

\begin{tabular}{|c|c|c|c|c|c|c|c|c|c|c|c|}
\hline \multicolumn{2}{|c|}{ Reference } & \multirow{2}{*}{$\begin{array}{l}\text { Age } \\
23\end{array}$} & \multirow{2}{*}{$\begin{array}{l}\text { Origin } \\
\text { Greek }\end{array}$} & \multirow{2}{*}{ 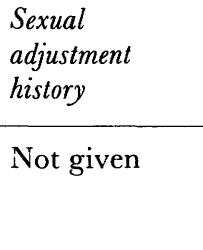 } & \multirow{2}{*}{$\begin{array}{l}\text { Accompanying } \\
\text { psychiatric } \\
\text { illness } \\
\text { Bipolar- } \\
\text { disorder } \\
\text { Anxiety }\end{array}$} & \multirow{2}{*}{ 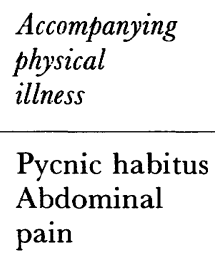 } & \multirow{2}{*}{$\begin{array}{l}\text { Fear of } \\
\text { shrinking } \\
\text { organ }\end{array}$} & \multirow{2}{*}{$\begin{array}{l}\begin{array}{l}\text { Fear of } \\
\text { death }\end{array} \\
\begin{array}{l}\text { Not } \\
\text { given }\end{array}\end{array}$} & \multirow{2}{*}{$\begin{array}{l}\text { Manoeuvers } \\
\begin{array}{l}\text { Not } \\
\text { given }\end{array}\end{array}$} & \multirow{2}{*}{$\begin{array}{l}\text { Treatment } \\
\text { Amitriptyline }\end{array}$} & \multirow{2}{*}{\begin{tabular}{|l} 
Outcome \\
$\begin{array}{l}\text { Not } \\
\text { given }\end{array}$
\end{tabular}} \\
\hline 1. & $\begin{array}{l}\text { Weller } \\
\text { \& Ameen } \\
(1982)\end{array}$ & & & & & & & & & & \\
\hline 2. & $\begin{array}{l}\text { Malinick } \\
\text { et al. } \\
\text { (1984) }\end{array}$ & 51 & $\begin{array}{l}\text { Black } \\
\text { USA }\end{array}$ & Single & $\begin{array}{l}\text { Anxiety; Sociopathy } \\
\text { Paranoidal } \\
\text { Homicidal }\end{array}$ & $\begin{array}{l}\text { Alcohol } \\
\text { abuse }\end{array}$ & Yes & Yes & $\begin{array}{l}\text { Not } \\
\text { given }\end{array}$ & $\begin{array}{l}\text { Not } \\
\text { given }\end{array}$ & Favourable \\
\hline 3. & $\begin{array}{l}\text { Emsley } \\
(1985)\end{array}$ & 25 & $\begin{array}{l}\text { Black } \\
\text { South- } \\
\text { African }\end{array}$ & Single & $\begin{array}{l}\text { Anxiety; Fear } \\
\text { of impotence } \\
\text { following } \\
\text { circumcision } \\
\text { Psychotic }\end{array}$ & Unknown & Yes & $\begin{array}{l}\text { Not } \\
\text { given }\end{array}$ & $\begin{array}{l}\text { Not } \\
\text { given }\end{array}$ & $\begin{array}{l}\text { Clomipramine } \\
\text { Haloperidol }\end{array}$ & $\begin{array}{l}<->\text { Deteriora- } \\
\text { tion } \\
<->\text { No response }\end{array}$ \\
\hline 4. & $\begin{array}{l}\text { Moodley } \\
\text { (1985) }\end{array}$ & 60 & Scottish & Married + 3 & $\begin{array}{l}\text { Benzodiazepine- } \\
\text { abuse } \\
\text { Anxiety } \\
\text { Depersonalization }\end{array}$ & $\begin{array}{l}\text { Cardiac } \\
\text { dysrhythmia } \\
\text { Drug abuse }\end{array}$ & Yes & No & No & $\begin{array}{l}\text { Not } \\
\text { given }\end{array}$ & $\begin{array}{l}\text { Not } \\
\text { given }\end{array}$ \\
\hline 5. & $\begin{array}{l}\text { Oyebode } \\
\text { et al. } \\
(1986)\end{array}$ & 56 & $\begin{array}{l}\text { Great } \\
\text { Britain }\end{array}$ & $\begin{array}{l}\text { Married } \\
\text { No children }\end{array}$ & $\begin{array}{l}\text { Major depression } \\
\text { Obsessions }\end{array}$ & $\begin{array}{l}\text { Change of } \\
\text { penis size }\end{array}$ & Yes & No & $\begin{array}{l}\text { Yes, } \\
\text { by wife }\end{array}$ & $\begin{array}{l}\text { Propranolol } \\
\text { thioridazine } \\
\text { dothiepine }\end{array}$ & Favourable \\
\hline 6. & $\begin{array}{c}\text { Joseph } \\
(1986)\end{array}$ & 32 & $\begin{array}{l}\text { Haiti } \\
\text { Black }\end{array}$ & Not given & $\begin{array}{l}\text { Atypical psychosis } \\
\text { Amnesia } \\
\text { Olfactory halluc. }\end{array}$ & $\begin{array}{l}\text { Psychomotor } \\
\text { epilepsy }\end{array}$ & Yes & Yes & Yes & Themazepam & Unfavourable \\
\hline 7. & $\begin{array}{c}\text { Joseph } \\
(1986)\end{array}$ & 32 & $\begin{array}{l}\text { Ethiopian } \\
\text { Black }\end{array}$ & Not given & $\begin{array}{l}\text { Paranoid psychosis } \\
\text { Olfactory halluc. }\end{array}$ & $\begin{array}{l}\text { Cerebral } \\
\text { atrophy; } \\
\text { Psychomotor } \\
\text { epilepsy }\end{array}$ & Yes & Yes & $\begin{array}{l}\text { Not } \\
\text { given }\end{array}$ & Haloperidol & Favourable \\
\hline 8. & $\begin{array}{l}\text { Modai } \\
\text { et al. } \\
(1986)\end{array}$ & 56 & $\begin{array}{l}\text { Israel } \\
\text { Born in } \\
\text { Iraq }\end{array}$ & $\begin{array}{l}\text { Married +3 } \\
\text { Hypersexual } \\
\text { Masturbation }\end{array}$ & $\begin{array}{l}\text { Anxiety; Immature- } \\
\text { personality; Guilt } \\
\text { \& depression }\end{array}$ & Healthy & Yes & No & Yes & $\begin{array}{l}\text { Clomipramine } \\
\text { Chlorprothixene } \\
+ \text { oxazepam }\end{array}$ & $\begin{array}{l}<->\text { Unfavour- } \\
\text { able } \\
<->\text { Improve- } \\
\text { ment }\end{array}$ \\
\hline
\end{tabular}




\begin{tabular}{|c|c|c|c|c|c|c|c|c|c|c|c|}
\hline 9. & $\begin{array}{l}\text { Kendall } \\
\text { \& Jenkins } \\
\text { (1987) }\end{array}$ & 34 & $\begin{array}{l}\text { Columbia } \\
\text { Black }\end{array}$ & Not given & $\begin{array}{l}\text { Schizophrenia } \\
\text { Anxiety; Delusions } \\
\text { of sexual change }\end{array}$ & Not given & Yes & $\begin{array}{l}\text { Not } \\
\text { given }\end{array}$ & Yes & Haloperidol & Favourable \\
\hline 10. & $\begin{array}{l}\text { Mukherjee } \\
\text { (1987) }\end{array}$ & 25 & $\begin{array}{l}\text { English } \\
\text { background }\end{array}$ & $\begin{array}{l}\text { Single; Sexual } \\
\text { inadequacy }\end{array}$ & $\begin{array}{l}\text { Bipolar disorder } \\
\text { Anxiety; } \\
\text { Emotionally } \\
\text { immature }\end{array}$ & Not given & Yes & $\begin{array}{l}\text { Not } \\
\text { given }\end{array}$ & $\begin{array}{l}\text { Not } \\
\text { given }\end{array}$ & $\begin{array}{l}\text { Amitriptyline } \\
\text { Trifluoperazine }\end{array}$ & Unfavourable \\
\hline 11. & $\begin{array}{l}\text { Devan } \\
(1987)\end{array}$ & 75 & $\begin{array}{l}\text { Singapore } \\
\text { Chinese- } \\
\text { origin }\end{array}$ & Widowed + 1 & $\begin{array}{l}\text { Depression; } \\
\text { Late-paranoid } \\
\text { schizophrenia }\end{array}$ & $\begin{array}{l}\text { Inguinal } \\
\text { hernia }\end{array}$ & Yes & Yes & Yes & $\begin{array}{l}\text { Neuroleptics } \\
\text { Family educ. } \\
\text { approach }\end{array}$ & Favourable \\
\hline 12. & $\begin{array}{l}\text { Holden } \\
\text { (1987) }\end{array}$ & 38 & Zulu & Married +5 & Anxiety & $\begin{array}{l}\text { Chronic } \\
\text { alcoholism; } \\
\text { Hepatitis; } \\
\text { UTI; } \\
\text { Vitamin def. }\end{array}$ & Yes & Yes & $\begin{array}{l}\text { Not } \\
\text { given }\end{array}$ & $\begin{array}{l}\text { Ampicillin } \\
\text { Diazepam } \\
\text { Multivitamins }\end{array}$ & Favourable \\
\hline 13. & $\begin{array}{l}\text { Scher } \\
(1987)\end{array}$ & 25 & $\begin{array}{l}\text { USA } \\
\text { Caucasian }\end{array}$ & $\begin{array}{l}\text { Single, } \\
\text { Excessive } \\
\text { masturbation } \\
+ \text { Guilt }\end{array}$ & $\begin{array}{l}\text { Learning disability } \\
\text { Memory } \\
\text { impairment }\end{array}$ & $\begin{array}{l}\text { Alcohol abuse } \\
\text { Hypertension }\end{array}$ & Yes & No & $\begin{array}{l}\text { Not } \\
\text { given }\end{array}$ & $\begin{array}{l}\text { Reassurance } \\
\text { Low dose BDZ } \\
\text { Perphenazine }\end{array}$ & Favourable \\
\hline 14. & $\begin{array}{l}\text { Kranzler } \\
\text { \& Shah } \\
(1988)\end{array}$ & 36 & Jamaica & Single & $\begin{array}{l}\text { Paranoid } \\
\text { schizophrenia; } \\
\text { Anxiety }\end{array}$ & $\begin{array}{l}\text { Swollen } \\
\text { testicles }\end{array}$ & $\begin{array}{l}\text { Yes }+ \\
\text { Shrinking } \\
\text { testes }\end{array}$ & Yes & Yes & $\begin{array}{l}\text { Fluphenazine } \\
\text { Lorazepam } \\
\text { Desipramine }\end{array}$ & $\begin{array}{l}\text { Moderate } \\
\text { improvement }\end{array}$ \\
\hline 15. & $\begin{array}{l}\text { Durst \& } \\
\text { Rosca } \\
(1988)\end{array}$ & 29 & $\begin{array}{l}\text { Israel } \\
\text { Rumanian- } \\
\text { origin }\end{array}$ & $\begin{array}{l}\text { Married + } 2 \\
\text { Excessive } \\
\text { masturbation } \\
+ \text { Guilt }\end{array}$ & $\begin{array}{l}\text { Panic attacks } \\
\text { Psychotic depression } \\
\text { Suicidal intention }\end{array}$ & $\begin{array}{l}\text { Tumour of } \\
\text { corpus } \\
\text { callosum }\end{array}$ & Yes & Yes & Yes & $\begin{array}{l}\text { E.C.T. } \\
\text { Clothiapine }\end{array}$ & Favourable \\
\hline 16. & $\begin{array}{l}\text { Westermeyer } \\
(1989)\end{array}$ & 31 & $\begin{array}{l}\text { USA } \\
\text { Born in } \\
\text { Laos }\end{array}$ & Married + 1 & $\begin{array}{l}\text { Psychotic depression } \\
\text { Shared delusional } \\
\text { disorder }\end{array}$ & $\begin{array}{l}\text { Previous } \\
\text { suspected } \\
\text { malaria }\end{array}$ & $\begin{array}{l}\text { Yes }+ \\
\text { Delusion of } \\
\text { sexual } \\
\text { change }\end{array}$ & No & No & $\begin{array}{l}\text { Not } \\
\text { given }\end{array}$ & $\begin{array}{l}\text { Not } \\
\text { given }\end{array}$ \\
\hline
\end{tabular}


Classification of Koro into three categories has been suggested by Devan and Hong (1987); as a discrete entity (classical koro), grafted upon an underlying psychiatric illness, and as a symptom of a mental illness. The present authors thought it justifiable to add a fourth category, namely that of Koro as a symptom of an organic disorder (Durst and Rosca-Rebaudengo, 1988). The sporadic cases compiled by Berrios and Morley (1984), those collected in the current work (Table 2), and the organic factors present in some of the epidemics, all reinforce the appropriateness of searching for a covert organic disorder in a patient with manifestations of koro.

The unshakable conviction of Koro sufferers that penile retraction is a prodrome of death is partly rooted in reality, since this is a phenomenon not seldom seen at death (Koro Study Team, 1969; Raven, 1886) due to decreased vasocongestion, arterial pressure and muscular tension (Edwards, 1984). Hyperbloating and intestinal distension upon death may also give the false impression of diminished penis size (Chowdhury, 1989).

Penile plethysmographic studies performed on a koro patient showed actual physiological changes in penile circumference (Oyebode et al., 1986).

Various extrinsic insults and intrinsic factors have been considered to elicit koro symptomatology. Among the possible extrinsic causes for penile contraction sudden exposure to cold (Devereux, 1954), contact with cold water (Edwards, 1984), and accidental physical trauma (Gould and Pyle, 1896) have been mentioned.

The syndrome was also reported to be associated with heroin withdrawal (Yap, 1965), drug abuse (Dow and Silver, 1973), alcohol hepatitis, avitaminosis, urinary tract infection (Holden, 1987), febrile episodes (Chowdhury, 1989) and cerebral malaria (Chakraborty et al., 1983). Attention to the physical condition may result in resolution of the koro symptomatology. Devereux (1954) stated that patients with gonorrheal urethritis and urinary tract infection often complain of a transient shortening of the penis due to reflex spasms.

The symptom choice of koro may revolve around sexual biomedical factors, interpersonal difficulties and intrapsychic conflicts. In the West Bengal epidemic (Chowdhury, 1989; Table 1) anatomo-sexual offenses, such as venereal disease and scrotal filaria, were demonstrated in a considerable number of patients. As these diseases may alter the anatomical dimesions of the sexual organs, the psycho-physiological sexual sensitivity does not remain intact. In the context of sexual functioning, extra-marital intercourse and failed attempts at sexual encounter may trigger penile hyperinvolution. Masters and Johnson (1966) suggested that penile retraction, like erection, is controlled by cortical centres.

Among the various maladies associated with koro, CNS pathology and dysfunction are increasingly implicated. The reason for this link must be sought in the greater awareness and accumulating knowledge concerning sporadic cases of koro, coupled with the sophisticated modern investigatory techniques (e.g. CT scan, MRI, BEAM). Contemporary publications describe cases of koro secondary to epileptic confusional states (Yap, 1965), 
temporoparietal dysfunction (epilepsy) (Joseph, 1986), cerebral syphilis (Yap, 1965), rabies (Suwanlert and Coates, 1979), cerebral malaria (Chakraborty et al., 1983), fronto-temporal tumour (Lapierre, 1972), and a tumour of the corpus callosum (Durst and Rebaudengo, 1988).

\section{References}

Adriani, N. and Kruijt, A. C. (1912). "De Bare'e-sprekende Toradja's van Midden-Celebes". Landsdrukkerij, Batavia.

Arieti, A. and Meth, J. M. (1959). Rare, unclassifiable, collective and exotic syndromes. In "American Handbook of Psychiatry", Volume 1, Basic Books, New York, p. 546.

Berrios, G. E. and Morley, S. J. (1984). Koro-like symptom in a non-Chinese subject. British Journal of Psychiatry, 145, 331-334.

Blonk, J. G. (1895). Koro. Geneeskundig Tijdschrift voor Nederlandsch-Indië, 35, 562-563.

Brero, P. C. J. van (1896). Eine Eigenthumliche Zwangsvorstellung. Allgemeine Zeitschrift für Psychiatrie und Medizin, 53, 569-573.

Bychowsky, G. (1943). Disorders of the body image in the clinical picture of psychoses. Journal of Nervous and Mental Diseases, 97, 310-335.

Chakraborty, A., Das, S. and Mukherji, A. (1983). Koro epidemic in India. Transcultural, Psychiatric Research, 20, 150-151.

Chowdhury, A. N. (1989). Biomedical potential for symptom choice in Koro. International Journal of Social Psychiatry, 35, 329-332.

Chowdhury, A. N. (1989). Penile perception of Koro patients. Acta Psychiatrica Scandinavica, 80, $183-186$.

Communion of Professional and Hospital Activities (1978). The International Classification of Diseases, 9th revision, Clinical Modification. Ann Arbor, Michigan.

Constable, P. J. (1979). Koro in Hertfordshire. Lancet, 1, 8108, 163.

Cremona, A. (1981). Another case of Koro in a Briton. British Journal of Psychiatry, 138, 180181.

Daroff, R. B., Deller, J. J., Kastl, A. J. and Blocker, W. W. (1967). Cerebral malaria. Fournal of the American Medical Association, 202, 119-122.

Devan, G. S. and Hong, O. S. (1987). Koro and schizophrenia in Singapore. British Journal of Psychiatry, 150, 106-107.

Devereux, G. (1954). Primitive genital mutilations in a neurotic's dream. Fournal of the American Psychoanalytic Association, 2, 484-492.

Diagnostic and Statistical Manual of Mental Disorders (1987). (3rd Edition, Revised). American Psychiatric Association, Washington, D.C.

Dow, T. and Silver, D. (1973). A drug induced Koro syndrome. Fournal of the Florida Medical Association, 60, 32-33.

Durst, R. and Rosca-Rebaudengo, P. (1988). Koro secondary to a tumour of the corpus callosum. British Fournal of Psychiatry, 153, 251-254.

Dutta, D. (1983). Koro epidemic in Assam. British fournal of Psychiatry, 143, 309-310.

Edwards, J. G. (1970). The koro pattern of depersonalization in an American schizophrenic patient. American Fournal of Psychiatry, 126, 1171-1173).

Edwards, J. W. (1984). Indigenous koro, a genital retraction syndrome of insular southeast Asia: a critical review. Culture, Medicine and Psychiatry, 8, 1-24.

Ellenberger, H. F. (1965). Ethnopsychiatrie. In. "Encyclopedie Medico-Chirurgicale". 37725B10. Paris.

Emsley, R. A. (1985). Koro in non-Chinese subjects. British Fournal of Psychiatry, 146, 102.

Gould, G. M. and Pyle, W. L. (1896). "Anomalies and Curiosities of Medicine". W. B. Saunders, Philadelphia.

Guazzo, F. M. (1608). "Compendium Maleficarum". English translation by E. A. Ashwin, 1929, London.

Gwee, A. L. (1968). Koro-its origin and nature as a disease entity. Singapore Medical Fournal, 9, 3-6. 
Harrington, J. A. (1982). Epidemic psychosis. British Fournal of Psychiatry, 141, 98-99.

Hes, J. P. and Nassi, G. (1977). Koro in a Yemenite and a Georgian Jewish immigrant. Confinia Psychiatrica, 20, 180-184.

Holden, T. J. (1987). Koro syndrome associated with alcohol-induced systemic disease in a Zulu. British Fournal of Psychiatry, 151, 695-697.

Hughes, C. C. (1985). The genital retraction taxon: commentary. In "The Culture-bound Syndromes: Folk Illnesses of Psychiatric and Anthropological Interest". (Eds. R. C. Simons and C. C. Hughes). D. Reidel, Dordrecht, The Netherlands.

Ilechukwu, S. T. G. (1988). Letter on koro-like syndromes in Nigeria. Transcultural Psychiatric Research Review, 25, 310-314.

Jilek, W. G. (1986). Epidermis of "genital shrinking" (koro): historical review and report of a recent outbreak in South China. Curare, 9, 269-282.

Joseph, A. B. (1986). Koro: computed tomography and brain electrical activity mapping in two patients. Fournal of Clinical Psychiatry, 47, 430-432.

Karo, J. B. E. (1488-1575). Shulchan Aruch (Codes of Law). Edition published by the R. Cook Institution, Jerusalem, 1975, p. 295.

Kendall, E. M. and Jenkins, P. L. (1987). Koro in an American man. American Journal of Psychiatry, 144, 1621.

Koro Study 'Team (1969). The Koro "epidemic" in Singapore. Singapore Medical Fournal, 10, 234-242.

Kraepelin, E. (1921). "Manic-Depressive Insanity and Paranoia". Livingston, Edinburgh.

Kranzler, H. R. and Shah, P. J. (1988). Atypical Koro. British Journal of Psychiatry, 152, 579580.

Lapierre, Y. D. (1972). Koro in a French Canadian. Canadian Psychiatric Association Fournal, 17, 333-334.

LeBar, F. M. (1972). "Ethnic Groups of Insular Southeast Asia. Volume I: Indonesia, Andaman Islands and Madagascar". Human Relations Area Files Press, New Haven, CT.

Levav, I. and Bilu, Y. (1980). A transcultural view of Israeli psychiatry. Transcultural Psychiatric Research Review, 17, 7-36.

Maimonides, M. (Rambam 1135-1204). Yad ha Chazaka: Issurei Biah, 21:18.

Malinick, C., Flaherty, J. A. and Jobe, T. (1985). Koro: how culturally specific? International Journal of Social Psychiatry, 31, 67-73.

Marshall, D. S. (1980). Too much in Mangaia. In "Readings in Human Sexuality: Comparative Perspectives", (Eds. G. Gordon and G. Johnson). Harper and Row, New York, pp. 236-240.

Masters, W. W. and Johnson, V. E. (1966). "Human Sexual Response", Little, Brown and Company, Boston.

Modai, I., Munitz, H. and Aizenberg, D. (1986). Koro in an Israeli male. British Fournal of Psychiatry, 149, 503-505.

Moodley, P. (1985). Koro in non-Chinese subjects. British Fournal of Psychiatry, 146, 102-103.

Mukherjee, T. (1987). Koro-like states. British Fournal of Psychiatry, 150, 881.

Nandi, D. N., Banerjee, G., Saha, H. and Boral, G. C. (1983). Epidemic Koro in West Bengal, India. International Fournal of Social Psychiatry, 29, 265-268.

Oyebode, F., Jamieson, R., Mullaney, J. and Davison, K. (1986). Koro-a psychophysiological dysfunction? British Fournal of Psychiatry, 148, 212-214.

Raven, T. (1886). Retraction of the penis. Lancet, 2, 250.

Rin, H. (1965). A study of the aetiology of Koro in respect to the Chinese concept of illness. International Journal of Social Psychiatry, 11, 7-13.

Rosenthal, S. and Rosenthal, P. A. (1982). Koro in an adolescent: hypochondriasis as a stress response. Adolescent Psychiatry, 10, 523-531.

Scher, M. (1987). Koro in a native born citizen of the U.S. International Fournal of Social Pscyhiatry, 33, 42-45.

Shukla, G. D. and Mishra, D. N. (1981). Koro-like syndrome. A case report. Indian fournal of Psychiatry, 23, 96-97.

Sprenger, J. and Kramer, H. (1489). "Malleus Maleficarum". English translation by Montague Summers, 1928, London. 
Suwanlert, S. and Coates, D. (1979). Epidemic koro in Thailand-clinical and social aspects. Transcultural Psychiatric Research Review, 16, 64-66.

Trethowan, W. H. (1963). The demonopathology of impotence. British Fournal of Psychiatry, 109, 341-347.

Tseng, W-S. (1973). The development of psychiatric concepts in traditional Chinese medicine. Archives of General Psychiatry, 29, 569-575.

Tseng, W-S., Kan-Ming, K., Hsu, J., Li-Shuen, L., Li-Wah, O., Guo-Qian, C. and Da-Wei, J. (1988). A sociocultural study of koro epidemics in Guangdong, China. American Fournal of Psychiatry, 145, 1538-1543.

Veith, I. (1972). "The Yellow Emperor's Classic of Internal Medicine". University of California Press, Berkeley.

Weller, M. P. I. and Ameen, N. (1982). Elvis Presley, reactive hypomania, and koro. American Fournal of Psychiatry, 139, 970.

Westermeyer, J. (1989). A case of koro in a refugee family: association with depression and folie à deux. Fournal of Clinical Psychiatry, 50, 181-183.

Wulfften Palthe, P. M. van (1934). Koro, een eigenaardige angstneurose. Geneeskundig Tijdschrift voor Nederlandsch-Indië, 74, 1713-1720.

Wulfften Palthe, P. M. van (1936). Psychiatry and neurology in the Tropics. In "A Clinical Textbook of Tropical Medicine", (Eds. C. D. de Langen and A. Lichtenstein). G. Kolff and Companie, Batavia, pp. 325-347.

Yap, P. M. (1951). Mental disorders perculiar to certain cultures: a survey of comparative psychiatry. Fournal of Mental Science, 97, 313-327.

Yap, P. M. (1965). Koro-a culture-bound depersonalization syndrome. British Fournal of Psychiatry, 111, 43-50. 




The Scientific World Journal


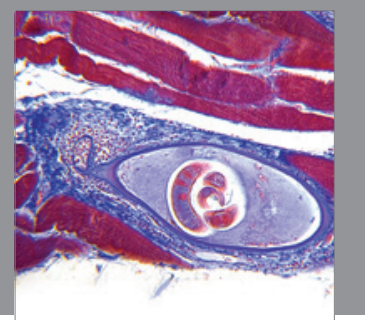

Gastroenterology

Research and Practice
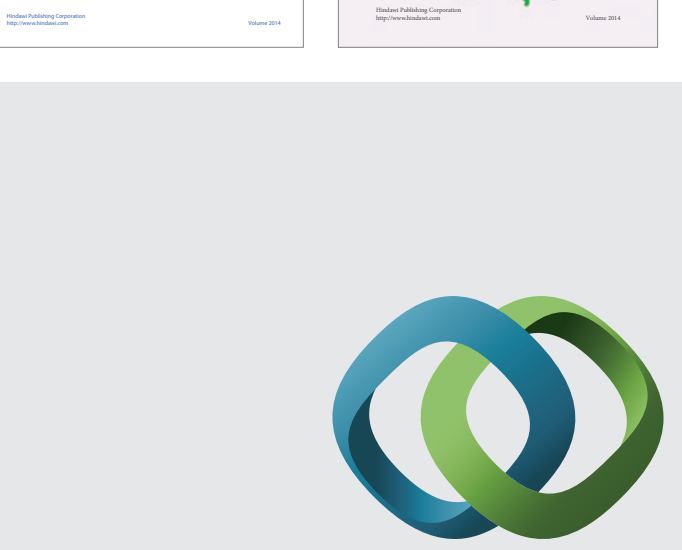

\section{Hindawi}

Submit your manuscripts at

http://www.hindawi.com
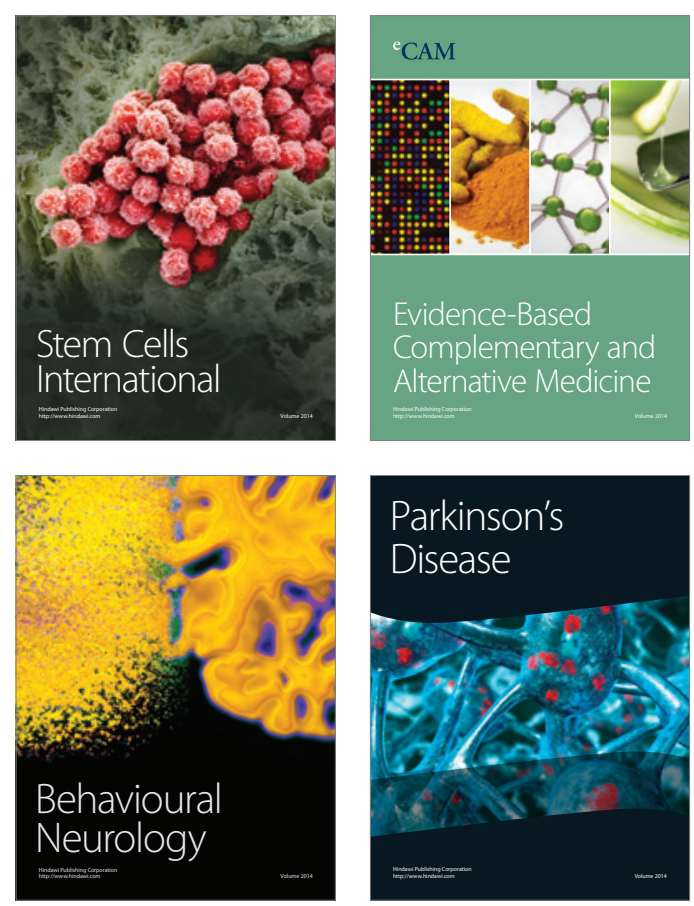

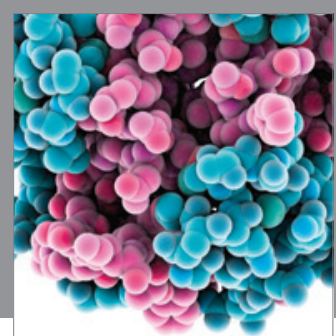

Journal of
Diabetes Research

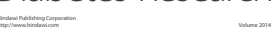

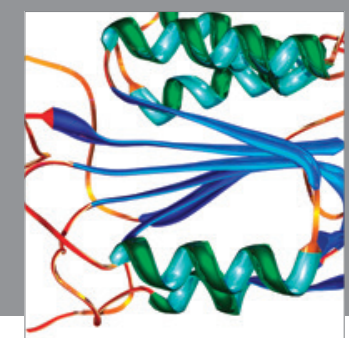

Disease Markers
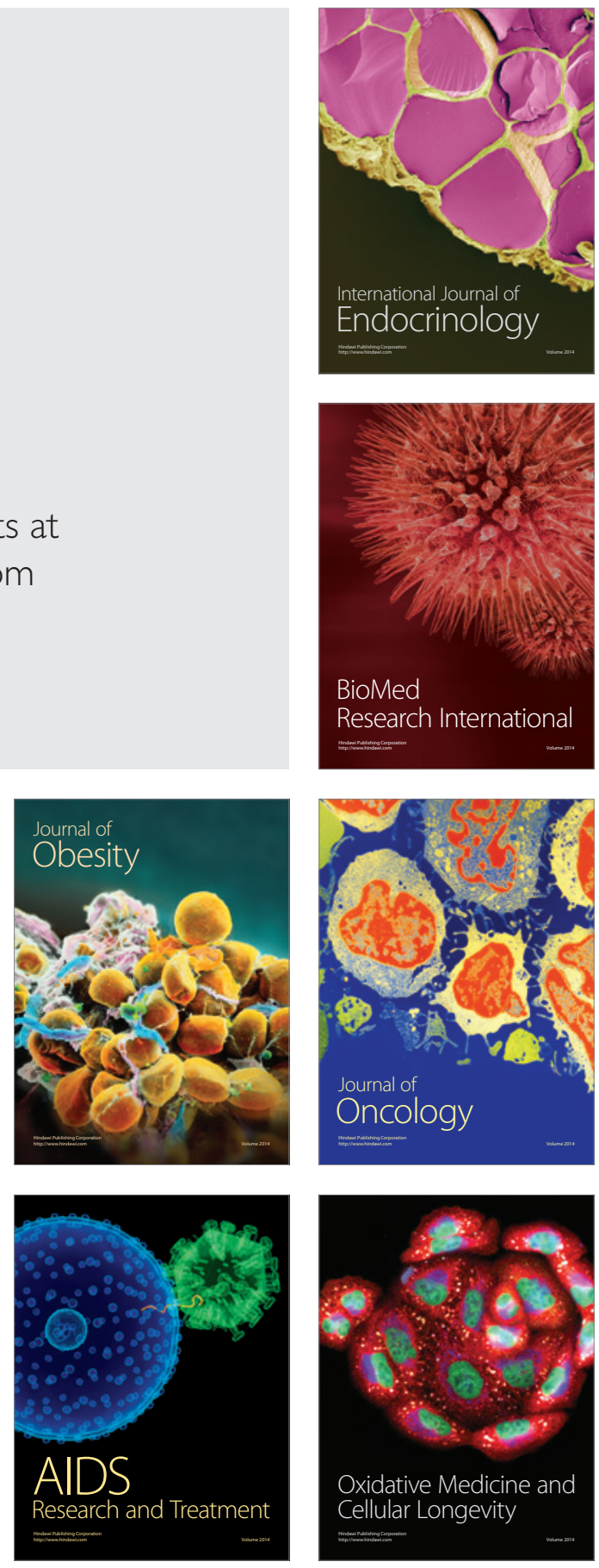